\title{
Surgical Management of Congenital Atresia Ani (Imperforate Anus) in a Madras Red Male Lamb
}

\author{
T. Kavanya ${ }^{1}$ and R. Rajendran ${ }^{2 *}$
}

${ }^{1}$ Network Project on Sheep Improvement (Madras Red), ${ }^{2}$ Post Graduate Research Institute in Animal Sciences, Tamil Nadu Veterinary and Animal Sciences University, Kattupakkam-603 203, Chengalpet district, Tamil Nadu, India

*Corresponding author

\section{A B S T R A C T}

\section{Keywords}

Atresia ani, congenital defect, Madras Red lamb

Article Info

Accepted:

11 June 2020

Available Online:

10 July 2020
A 10 days old Madras Red male lamb was observed with complaints of absence of defecation, abdominal distension, discomfort and tenesmus. On examination, it had been observed that there was no anal opening. It was diagnosed as atresia ani, which is a failure of development of the anal opening. Surgical treatment is the only course of action. This paper reports a case of male sheep with atresia ani and also gives the surgical procedure adopted. The culling of sire, dam and the affected animal is suggested to prevent the occurrence of this defect in future.

\section{Introduction}

Congenital anomalies of gastro intestinal tract occur among different species of animals with an incidence of about $4.3 \%$ (Leipold et al., 1971). Atresia ani (imperforate anus) is a common congenital anomaly that has been reported in all domestic animals and is one of the most frequently recorded defects of intestine among sheep because of autosomal recessive gene (Bademkiran et al., 2009). The term atresia describes congenital occlusion of the lumen of the digestive tract. "Imperforated anus", sometimes termed as atresia ani, is due to failure of the anal membrane to break down during the development (McGeady et al., 2006).

There are four major types of atresia ani which consists of type I-IV. In type I, a mucosal barrier obstructs the lumen of the intestine. Animals with type II have an intestine with two segments without any communication usually with a fibrous cord joining them together. In type III, two segments of intestine separated completely which may be coiled at the distant end in some animals. 
In Type IV, multiple site of atresia are involved (Bademkiran et al., 2009; Rahal et al., 2007). Atresia ani is manifested clinically by an absence of faeces, dullness, anorexia with abdominal distension, discomfort, straining to an attempt to defaecate. Surgical treatment is the only course of action. The present paper describes a case of atresia ani in a 10 days old Madras Red lamb. In the present case, we report a successful surgical correction of atresia ani where the lamb showed marked improvement in defecation with minimum tenesmus.

\section{History and diagnosis}

A farmer in Kayarambedu village of Chengelpet District, who is covered under Network Project on Madras Red sheep Improvement, had a flock with a size of 50, nearly 30 breedable ewes and 20 lambs. This flock had a ram supplied from the scheme. On the day of field visit, he complained of absence of defaecation since birth in the male lamb of 10 days old. On clinical observation, it was observed that the lamb was not having anal opening. There was a soft subcutaneous swelling below the ischial arch with distension of abdomen. The tenesmus and abdominal pain were observed. Based on the clinical signs and the physical examination, the case was diagnosed as atresia ani and planned for surgery.

\section{Surgical procedure}

The lamb was placed in a lateral recumbency with its hind quarter raised high. The perineal region was prepared for aseptic surgery. Local infiltration using injection 2\% Lignocaine hydrochloride was done at the perineal region below the tail. An incision was made on the bulge of the anus to remove a circular piece of skin. The rectum was exposed by separation of the perineal muscles. The blind end of the rectum was brought to the level of sphincter ani and fixed to the perineum after duly snipping the tip of the blind end of the rectum. After opening, expulsion of gas and muconium was observed. Gas and muconium was also removed by gentle pressure. The patency is maintained by application of interrupted sutures using braided black silk No. 1 on the circumference of the rectal opening between the rectal mucosa and the skin to keep the anal orifice permanent. The animal was administered Enrofloxacin @ $5 \mathrm{mg} / \mathrm{kg}$ for five days and meloxicam @0.5 ml for 3 days; routine dressing with povidone iodine ointment and application of topicure spray as a fly repellant. The lamb showed normal in defecation with minimum tenesmus and active in nature on the 3rd postoperative day and therefore the sutures were removed on 10th post-operative day and the animal made a noticeable recovery.

Atresia ani is the most common intestinal defect in sheep and usually arises during the embryonic period which results from autosomal recessive gene (Loynachan et al., 2006). Though environmental teratogens, plant toxins and a few viruses are recognised complicating factors in calves (Loynachan et al., 2006). In the present case, the reason could not be ascertained and unspecific.

In a series of 64 cases of atresia ani in sheep, $42(62 \%)$ were associated with defects of other body systems, especially the urogenital and musculoskeletal systems (Kilic et al., 2004; Rahman et al., 2006). This condition may be associated with recto-vaginal fistula, recto-cystic fistula, vagino urethral agenesis, taillessness, hypospadias and diphallus (Loynachan et al., 2006). But, in this present study, atresia ani was observed alone without any other anomaly. According to Radostitis et al., (2000), the affected animals may survive for up to 10 days and diagnosed by their depression, anorexia, colic, marked gradual abdominal distension and lack of feces. 
Atresia ani can be diagnosed by simple visual examination or by digital palpation and the clinical signs. Surgical intervention is the only choice of treatment to be done immediately and it was attempted successfully in the present case. Atresia ani is fatal affection to the male unless surgical correction is carried out to provide anal opening. Atresia ani doesn't need special attention in case of female since rectum frequently break through to vagina forming a rectovaginal fistula and thus permit defecation via the vulva and sometimes may not be identified (Norrish and Rennie, 1968).

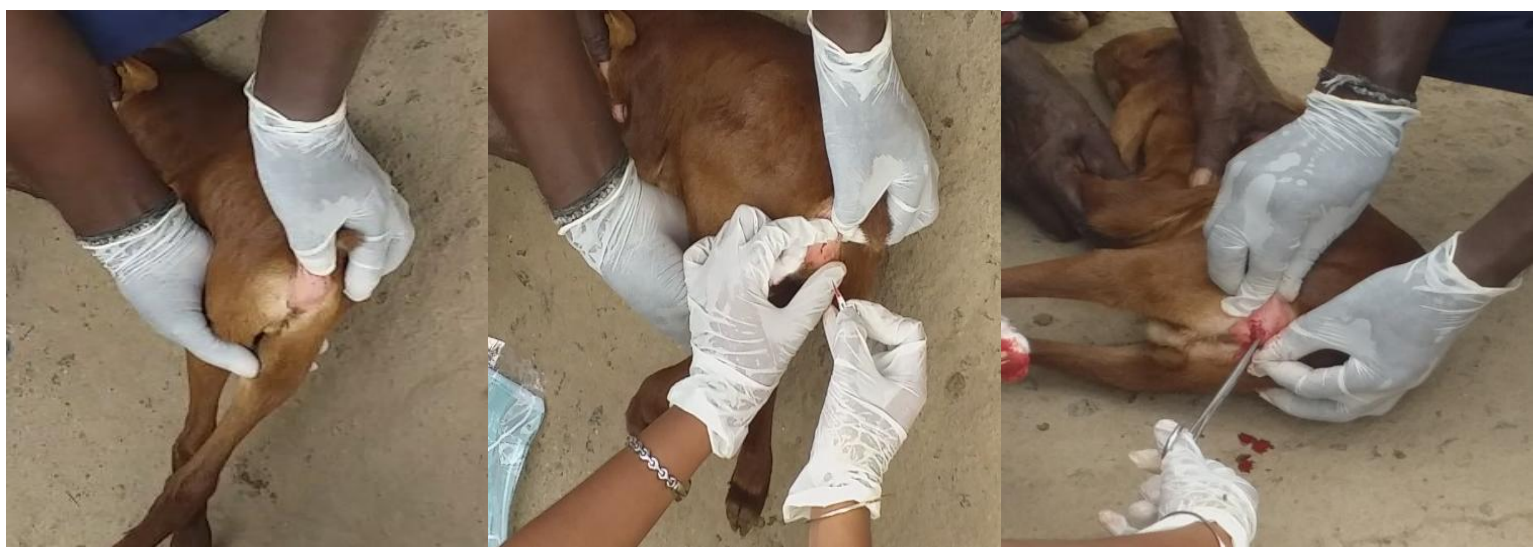

Fig.1 Pre-operative photograph of lamb perineal area showing absence of anal opening

Fig.2 Intra-operative photograph of lamb perineal area showing the circular incision at rectum Fig.3 Intra-operative photograph of lamb perineal area showing widening of the incised region using forceps

The other lambs born to this only ram in the flock were also screened for this abnormality and no such abnormality was found in the other lambs. The dam of the affected lamb was also examined for recto-vaginal fistula, which was also absent.

The genetic abnormality due to an autosomal recessive gene can occur only in homozygous condition. Both sire and dam should pass the gene to the progeny for this condition to occur i.e., both sire and dam should carry at least one copy of the gene. Hence, sire and dam of the affected animal should not further be used for breeding to prevent occurrence of this condition.

The affected animal also should not be bred in future. The farmer was advised to cull both the ewe and lamb. The ram was also removed from the flock to prevent further breeding.

It is suggested that the young animals must be examined thoroughly after birth, particularly for atresia ani and treated instantly to save their lives.

\section{Acknowledgement}

The authors are thankful to the Professor and Head, Post Graduate Research Institute in Animal Sciences, Tamil Nadu Veterinary and Animal Science University, Chennai for providing necessary assistance to carry out the work.

\section{References}

Bademkiran, S., Icen, H., Kurt, D. (2009). Congenital recto vaginal fistula with atresia ani in a heifer: a case report. YYU Veteriner Fakultesi Dergisi, 20(1), 61-64.

Kılıç, N. and Sarierler, M. (2004). Congenital intestinal atresia in calves: 61 cases 
(1999-2003). Revue Méd Vét., 155

(7),381-384.

Leipold,H.W., Dennis, S.M. and Huston, K.

(1971). Congenital defects of cattle:

Nature, cause, and effect. Advances in

Veterinary Science and Comparative

Medicine, 16, 103-150.

Loynachan, A.T., Jackson, C.B. and Harrison,

L.R. (2006). Complete diphallia, imperforate ani (type 2 atresia ani), and an accessory scrotum in a 5-day-old calf. Journal of veterinary diagnostic investigation, 18(4), 408-412.

McGeady, T. A., Quinn, P. J. and FitzPatrick, E. S. (2006). Veterinary Embryology. Wiley-Blackwelly, p 222.

Norrish, J. and Rinnii, J. (1968). Obervations on the Inheritance of Atresia Ani in
Swine. J Hered., 59, 186-187..

Radostitis, O.M., Gay, C.C., Blood, D.C. and Hinchcliff, K.W.(2000). Veterinary Medicine: A Textbook of the Diseases of Cattle, Sheep, Pigs, Goats and Horses, 9th ed., Saunders Company, Philadelphia, USA, pp.1729.

Rahal, S.C., Vicente, C.S., Mortari, A.C., Mamprim,M.J., Caporalli, E.H. (2007). Rectovaginal fistula with anal atresia in 5 dogs. The Canadian Veterinary Journal, 48(8), 827.

Rahman, M.M., Khan, M.S.I., Biswas, D., Sutradhar, B.C., Saifuddin, A.K.M. (2006). Pygomelia or supernumerary limbs in a crossbred calf. J Vet Sci, 7(3), 303-305.

\section{How to cite this article:}

Kavanya. T. and Rajendran. R. 2020. Surgical Management of Congenital Atresia Ani (Imperforate Anus) in a Madras Red Male Lamb. Int.J.Curr.Microbiol.App.Sci. 9(07): 887-890. doi: https://doi.org/10.20546/ijcmas.2020.907.102 